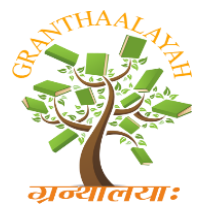
INTERNATIONAL JOURNAL OF RESEARCH GRANTHAALAYAH A knowledge Repository

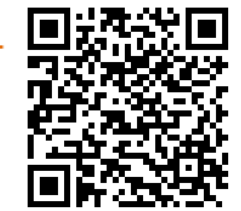

Social

\title{
ANECDOTES AND CONTOURS OF HIGHER EDUCATION IN INDIA
}

\author{
Dr. Gopal Krishna Thakur *1 \\ ${ }^{* 1}$ School of Education, MGAHV, Wardha, Maharashtra, INDIA
}

\begin{abstract}
Higher education is considered as an invaluable instrument for the sustainable development of human being and society through a dynamic process of creation, advancement, and dissemination of knowledge. In a fast developing country like India the role of higher education assume utmost importance. Universities have a pivotal role in realizing this goal. Our higher education system has had a glorious past in the form of world-class universities like Nalanda, Vikramsila, and Taxila, which attracted students and intellectuals from all over the world those days. However, in the present time we are lagging far behind in terms of qualitative education and research. This necessitates a serious concern and introspection to look into the nuances and flaws of our system that make our higher education system stand at where it is now. This paper, based on the analysis of various reports and Govt. documents, discusses some of the issues, which are at the core of the main concerns pertaining to higher education in India. Taking a snapshot of the historical trajectory of higher education system in India to the present time, this paper presents an overview of the higher education system in India and points out some most relevant concerns troubling the issue at the core.
\end{abstract}

Keywords:

Higher Education, Faculty wise Enrolment, Level wise Enrolment, Historical Anecdotes, Genesis of Present System, Expansion of Universities.

Cite This Article: Dr. Gopal Krishna Thakur, “ANECDOTES AND CONTOURS OF HIGHER EDUCATION IN INDIA" International Journal of Research - Granthaalayah, Vol. 3, No. 11(2015): 35-42. DOI: https://doi.org/10.29121/granthaalayah.v3.i11.2015.2914.

\section{INTRODUCTION}

Education and literacy are the most important indicators of development in any society across the globe. Education is perceived as one of the crucial instruments of the national development and higher education, in particular, is of utmost importance for the nation, as it is a powerful tool to build knowledge-based society of the 21 st century. The contribution of higher education is vital to the national innovation system and the development of human resources.

In a fast developing country like India, improvement of access along with equity and excellence, adoption of states-specific strategies enhancing the relevance of higher education through 
curriculum reforms, vocational education, information technology, networking, and distance education are some of the main policy initiatives of the higher education sector being talked about in the last few years. The other important policy initiatives in higher education are - programmes for general development of universities and colleges; special grants for the construction of hostels for women; scholarships to students; scheme to provide interest subsidy on educational loans for professional courses in order to ensure that nobody is denied professional education because of financial constraints; and making interventions to attract and retain talents in the teaching profession in the higher and technical education sector. In the last couple of years, emphasis has been laid on expansion with equity, use of ICT and promotion of quality education.

Rapid technological advancement and adoption of liberalization, privatization and globalization have brought the higher education into an era full of challenges and prospects. Growing demand of accessibility to Higher Education lays huge infusion of funds on Government but during the last decades there is a growing trend of Governmental withdrawal from the education sector, especially from higher education sector. This has culminated into exponential increase of private sectors in higher education and Public Private Partnership (PPP) in order to bridge the gap between demand $\&$ supply. On the other side, it seems that quality is not keeping pace with quantity. Quality cannot come only with investment of funds and developing infrastructure by the private funding but quality of consciousness, resource mobilization through Public Private Partnership and its proper management are keys to quality in Higher Education. Government of India has been working on formulation and implementation of various plans and strategies to revamp the current educational system and make it more relevant to the needs of society. In this regard, Rashtriya Uchchatar Shiksha Abhiyan (RUSA), Foreign Education Providers (FEP) Bill, Special Education Zone (SEZ), restructuring of U.G.C., NCTE \& AICTE are some of the steps that Govt. has been pursuing of late.

\section{HISTORICAL ANECDOTES}

From ancient Bharat to modern India, higher education has always occupied a place of prominence in Indian history. In ancient times, Nalanda, Takshila and Vikramshila universities were renowned seats of higher learning, attracting students not only from all over the country but from far off countries like Korea, China, Myanmar, Sri Lanka, Tibet and Nepal. Today, India manages one of the largest higher education systems in the world.

India inherited an age old tradition of higher education system which had generated knowledge and learning right from the beginning of Indian civilization. To take into consideration the reign of the Guptas' they encouraged higher learning by patronizing centers of higher education at Nalanda, Takshila, Ujjain, Vikramshila and Vallabhi. Each university, as mentioned, specialized in a particular field of study. Takshila was renowned in the study of medicine, while Ujjain was famous for astronomy. Nalanda, since it was the biggest center and locational advantage, handled all branches of knowledge. As a matter of fact during the Gupta period, India became a renowned center for higher studies by attracting scholars from all parts of India and from several foreign countries.

These universities became even popular in the seventh and eighth centuries A.D. After the advent of Buddhism, people flocked to the Sarnath University to study Buddhist religion and to Ajanta to 
specialize in art, architecture, and painting. These educational institutions were mainly financed by grants of land and liberal donations. Such grants and donations came from kings as well as from other affluent people existing in the-then society. In fact, historical data figures out a wellestablished system of higher education which functioned in India as early as 1000 B.C. "In that system, the construction of knowledge, the beliefs on which knowledge is based, basic concepts and the organization of learning were very different from the European tradition.

\section{THE GENESIS OF PRESENT SYSTEM OF HIGHER EDUCATION IN INDIA}

The present system of higher education dates back to "Mountstuart Elphinstone's minutes of 1823", which stressed on the need for establishing schools for teaching English and the European sciences'". Later, Lord Macaulay, in his minutes of 1835, advocated "efforts to make natives of the country thoroughly good English scholars".' Sir Charles Wood's Dispatch of 1854, famously known as the 'Magna Carta of English Education in India', recommended creating a properly articulated scheme of education from the primary school to the university. It sought to encourage indigenous education and planned the formulation of a coherent policy of education. Subsequently, the universities of Calcutta, Bombay (now Mumbai) and Madras were set up in 1857, followed by the University of Allahabad in 1887. The Inter-University Board (later known as the Association of Indian Universities) was established in 1925 to promote university activities, by sharing information and cooperation in the field of education, culture, sports and allied areas. The first attempt to formulate a national system of education in India came in 1944, with the Report of the Central Advisory Board of Education on Post War Educational Development in India, also known as the Sargent Report. It recommended the formation of a University Grants Committee, which was formed in 1945 to oversee the work of the three Central Universities of Aligarh, Banarasand Delhi. In 1947, the Committee was entrusted with the responsibility of dealing with all the then existing Universities. Soon after Independence, the University Education Commission was set up in 1948 under the Chairmanship of Dr. S Radhakrishnan "to report on Indian university education and suggest improvements and extensions that might be desirable to suit the present and future needs and aspirations of the country". It recommended that the University Grants Committee be reconstituted on the general model of the University Grants Commission of the United Kingdom with a full-time Chairman and other members to be appointed from amongst educationists of repute. In 1952, the Union Government decided that all cases pertaining to the allocation of grantsin-aid from public funds to the Central Universities and other Universities and Institutions of higher learning might be referred to the University Grants Commission. Consequently, the University Grants Commission (UGC) was formally inaugurated by late Shri Maulana Abul Kalam Azad, the then Minister of Education, Natural Resources and Scientific Research on 28 December 1953. The UGC, however, was formally established only in November 1956 as a statutory body of the Government of India through an Act of Parliament for the coordination, determination and maintenance of standards of university education in India.

From 1947 till date, three important commissions for suggesting educational reforms have been appointed by the Government of India. As discussed in the preceding paragraph, the first commission was University Education Commission under the chairmanship of Dr. S. Radhakrishnan of 1948 - 49, whichmade valuable recommendations regarding the reorganization of courses, techniques of evaluation, medium of instruction, student services, and the recruitment of teachers. The Secondary Education Commission of 1952-53 was appointed by the Indian 
Government to examine the prevailing system of secondary education in the country and to suggest measures for its re-organization and improvement with reference to the aims, organization, and content of secondary education, its relationship to primary and higher education, and the interrelation of secondary schools of different types. Dr. A. Lakshmanaswami Mudaliar, ViceChancellor of Madras University was appointed as the Chairman of this commission. The commission though focused mainly on secondary and teacher education however, touched upon the system of higher education in India, specifically to teacher education system in the country and suggested some important roadmaps for the linkage of teacher education between school education to different levels of college and university education.

The third and perhaps the most important commission so far has been the Education Commission of 1964-66. It was appointed by the Govt. of India under the Chairmanship of Dr. D.S. Kothari, the then Chairman of University Grants Commission (U.G.C.). The commission made a comprehensive review of the entire field of education. It developed a national pattern for all stages of education. The commission's report led to a resolution on a national policy for education, formally issued by the government of India in July 1968. This policy was revised in 1986. The new policy emphasized educational technology, ethics, and national integration. A core curriculum was introduced to provide a common scheme of studies throughout the country. The present $10+2+3$ system of education came into existence throughout India as a result of the implementation of New Education Policy - 1986.

The national department of education was a part of the Ministry of Human Resource Development, headed by a cabinet minister. A Central Advisory Board of Education counseled the national and state governments. There were several autonomous organizations attached to the Department of Education. The most important bodies were the All-India Council of Technical Education (1945), the University Grants Commission (1953), and the National Council of Educational Research and Training (1961). The first body advised the government on technical education and maintained standards for the development of technical education. The second body promoted and coordinated university education and determined and maintained standards of teaching, examination, and research in the universities. It had the authority to enquire into the financial methods of the universities and to allocate grants. The third body worked to upgrade the quality of school education and assisted and advised the Ministry of Human Resource Development in the implementation of its policies and major programs in the field of education.

\section{EXPANSION OF UNIVERSITIES IN INDIA}

At the time of independence, India had only 20 Universities and 500 Colleges with 210,000 students enrolled in higher education institutions. However, the post-independent India has witnessed a phenomenal increase in terms of academic facilities compared to what was there at the time of independence. And the last two decades have proven to be phenomenal in terms of quantitative growth of academic institutions in India across States.

The following table presents the growth in number of Universities under different types of management in the last four years. 
Table 1: Total No. of Universities in the Country

\begin{tabular}{|l|l|l|l|l|}
\hline Universities & As on 31-03-2011 & As on 31-03-2012 & As on 31-03-2013 & As on 05-02-2014 \\
\hline Central Universities & 43 & 44 & 44 & 45 \\
\hline State Universities & 265 & 286 & 306 & 312 \\
\hline Deemed to be Universities & 130 & 129 & 129 & 129 \\
\hline Private Universities & 80 & 111 & 154 & 173 \\
\hline Total & $\mathbf{5 1 8}$ & $\mathbf{5 7 0}$ & $\mathbf{6 3 3}$ & $\mathbf{6 5 9}$ \\
\hline
\end{tabular}

Source: UGC / MHRD

\section{Students' Enrolment}

Enrolment in the academic institutions all over India has also increased over the years. In fact, the increase is exponential in terms of enrolment of students at all level of education. The following table presents the status of students' enrolment in Universities and colleges.

Table 2: All India Growth of Students Enrolment in Universities/Colleges:2000-01 to 2011-12

\begin{tabular}{|l|l|l|l|}
\hline Year & Total Enrolment & Increase Over the Preceding Year & Percentage \\
\hline $2000-01$ & 8399443 & 348836 & 4.3 \\
\hline $2001-02$ & 8964680 & 565237 & 6.7 \\
\hline $2002-03$ & 9516773 & 552093 & 6.2 \\
\hline $2003-04$ & 10201981 & 685208 & 7.2 \\
\hline $2004-05$ & 11038543 & 836562 & 8.2 \\
\hline $2005-06$ & 12043050 & 1004507 & 9.1 \\
\hline $2006-07$ & 13163054 & 1120004 & 9.3 \\
\hline $2007-08$ & 14400381 & 1237327 & 9.4 \\
\hline $2008-09$ & 15768417 & 1368036 & 9.5 \\
\hline $2009-10$ & 17243352 & 1474935 & 9.4 \\
\hline $2010-11$ & 18670050 & 1426698 & 8.3 \\
\hline $2011-12$ & 20327478 & 1657428 & 8.9 \\
\hline
\end{tabular}

Source: Various Reports ofMHRD / U.G.C. Reports

Figures of students' enrolment, presented in Table 2, pertain to regular courses in universities and colleges (excluding Polytechnics, other diploma awarding Institutions \& Non-formal system of Higher Education). The data presented in the table above shows that the percentage increase in student's enrolment compared to preceding year has just doubled in year 2011-12 compared to that in year 2000-01. If we compare the present data of enrolment with the one at the time of independence, the magnitude is certainly much more. However, there are many factors that have impacted the existing status of enrolment. The character of our society has been transforming over the period of time from agrarian to industrial and urban centric society. This has had a pressing demand on the population to look for the avenues in the areas other than agriculture and that subsequently pushed the masses to get into skill development and education $\&$ training for various occupations. Eventually, the education sector is being looked upon to have key to the various career avenues. Thus the pressure on education sector has increased as the population has increased and the social mobility in terms of economic activities has increased.

One noticeable fact regarding students' enrolment in higher education is that the percentage of students' enrolment decreases as we move on from first degree to post-graduate degree to research degree. Though there could be more than one reason to explain the variations in students' enrolment at various levels of higher education ranging from availability of educational institutions in a particular area to choices of students and opportunities that they are provided with. The 
following table presents the facts and figures about the students' enrolment in colleges and university departments at various levels of education in the year 2011-12.

Table 3: Level wise Enrolment of Students in University departments/University Colleges/Affiliated Colleges (Year 2011-12)

\begin{tabular}{|l|l|l|l|l|l|l|}
\hline S. No. & Level & $\begin{array}{l}\text { University } \\
\text { Departments / } \\
\text { University } \\
\text { Colleges }\end{array}$ & $\begin{array}{l}\text { Affiliated } \\
\text { Colleges }\end{array}$ & Total & $\begin{array}{l}\text { Percentage } \\
\text { of Grand } \\
\text { Total }\end{array}$ & $\begin{array}{l}\text { Percentage } \\
\text { in Affiliated } \\
\text { Colleges }\end{array}$ \\
\hline 1 & Graduate & 1853109 & 15602420 & 17455529 & 85.87 & 89.38 \\
\hline 2 & Post-Graduate & 693864 & 1798608 & 2492472 & 12.26 & 72.16 \\
\hline 3 & Research & 127780 & 33092 & 160872 & 0.79 & 20.57 \\
\hline 4 & Diploma / Certificate & 132620 & 85985 & 218605 & 1.08 & 39.33 \\
\hline & Grand Total & $\mathbf{2 8 0 7 3 7 3}$ & $\mathbf{1 7 5 2 0 1 0 5}$ & $\mathbf{2 0 3 2 7 4 7 8}$ & $\mathbf{1 0 0 . 0 0}$ & $\mathbf{8 6 . 1 9}$ \\
\hline
\end{tabular}

Source: MHRD / U.G.C. Reports

From the facts presented in the Table-3, it is evident that the graduate level enrolment is quite substantial $(85.87 \%)$ of the total enrolment. But the same doesn't hold true for the enrolment at post-graduate level $(12.26 \%)$ and at the research level $(0.79 \%)$. Specifically the research area is one such area where we need to put in more and more resources and efforts to attract bright students to promote research across all disciplines of education.

Also, subject wise variations in enrolment seem quite prominent in some cases, particularly when looked at from one end of the continuum to the other end. The following Table-4 gives an account of the subject wise students' enrolment in higher education in Year 2011-12:

Table 4: Students Enrolment: Faculty Wise: 2011-12

\begin{tabular}{|l|l|l|l|}
\hline S. No. & Faculty & Total Enrolment & Percentage of Total \\
\hline 1 & Science & 3789967 & 18.64 \\
\hline 2 & Arts & 7539495 & 37.09 \\
\hline 3 & Commerce / Management & 3571083 & 17.57 \\
\hline 4 & Education & 732627 & 3.60 \\
\hline 5 & Engineering / technology & 3261590 & 16.05 \\
\hline 6 & Medicine & 715706 & 3.52 \\
\hline 7 & Agriculture & 97313 & 0.48 \\
\hline 8 & Veterinary Science & 28504 & 0.14 \\
\hline 9 & Law & 373246 & 1.84 \\
\hline 10 & Others* & 217947 & 1.07 \\
\hline & Total & $\mathbf{2 0 3 2 7 4 7 8}$ & $\mathbf{1 0 0 . 0 0}$ \\
\hline
\end{tabular}

*Others include Library and Information Science, Music, Performing / Visual Arts, Journalism \& Mass Communication, Physical Education and Social Work etc.

\section{DISCUSSIONS}

The data presented in the Table-4 indicate that Arts \& Humanities dominate in terms of students' enrolment. Whereas, Science, Commerce \& Management, and Engineering \& Technology disciplines are about fifty percent of the students' enrolled in Arts \& Humanities subjects. This suggests the present trend of students' inclination towards various disciplines.

However, the most important dimension of education, which is missing, is the qualitative improvement of the system and its output that is a major concern at present. As we know so far 
none of the Indian Universities had any place in the world's top two hundred universities' list. Only this time, the Indian Institute of Science (IISc) Bangalore broke India's poor ranking spell by making a debut in the world's top 100 universities for engineering and technology. IISc made its entry at 99th spot in a list that remains dominated by US institutions with Stanford, CalTech and Massachusetts Institute of Technology (MIT) in the top three positions in the 'Times Higher Education (THE) Ranking for Engineering \& Technology'(The Indian Express, Nov. 12, 2015). This seems encouraging on one hand, however the status of our educational system raises some serious concerns regarding where we should have been by now, on the other hand as well. Addressing this issue is imperative in the present global context where India is making efforts to become one of the world powers.

\section{CONCLUSION}

With the rapid growth in population and subsequent increase in the demand of education, especially higher education, the country needs quality higher education institutions in adequate number to meet the demand of the people. However, the role of government is not relinquished by paving way for the private sectors in higher education. The governmental role is very crucial in maintaining quality in education. The regulatory authorities do exist but their monitoring needs to be transparent and impartial. Only then the rule of law can prevail and we can hope for a better education system imparting quality education to the students. The success of a higher education system is not only dependent on the number of enrolment or revenue that it generates, but also the success of a higher education system manifests in the form of its graduated students doing well in their professional field, research work being carried out in the various departments of the universities, contribution being made to the body of knowledge and promoting a wholesome learning environment and a vibrant and thriving knowledge society. For this, the onus is on each and every stake holders of the higher education system in particular and education system in general as well as on the society at large.A whole hearted effort is needed from all stakeholders of the society in order to realize this goal; otherwise it will remain as a farfetched dream only.

\section{REFERENCES}

[1] Dhar B.B. (2008). Higher Education System, New Delhi: A.P.H. Publishing Corporation

[2] Government of India, Economic Survey (2012-13), New Delhi: Ministry of Finance

[3] Government of India, National Sample Survey Organisation (2007-08), 61st and 64th round, New Delhi: NSSO

[4] Government of Maharashtra, Road map (2010-15), Mumbai: Department of Higher and Technical Education

[5] Gupta S. \&Gupta M. (1997). Higher Education in 21st Century, New Delhi:Anmol Publications Pvt. Ltd.

[6] Modi, H. \&Mukhopadhyay A. (2002).An Analysis of Tax Concessions of Charitable Organizations, New Delhi: NIFP

[7] Mukherjee, A.(2002). The Making of the Indian Bourgeoisie, New Delhi: Sage Publications

[8] Rani, G. (2002).Financing Higher Education in India. NIEPA Working Paper

[9] Rao, D.B. (2003). Higher Education in 21st Century, New Delhi: Discovery Publishing House

[10] Sidel, M. (2002).Review Article on Philanthropy in South Asia, Voluntas 
[11] Sundar, P.(2000). Beyond Business: From Merchant Charity to Corporate Citizenship. New Delhi: Tata MaCGraw Hill

[12] University Grants Commission (2012), Higher Education in India at a glance, New Delhi: U.G.C.

[13] http://indianexpress.com/article/india/india-news-india/iisc-makes-indian-debut-in-top100-world-university-ranking/ 